\title{
Associations of the -344T>C polymorphism of CYP11B2 gene with 24-hour blood pressure profiles in middle-aged women with essential hypertension
}

\author{
Marta Sołtysiak, Tomasz Miazgowski, Joanna Ziemak, Paweł Sołtysiak, Krystyna Widecka
}

Department of Hypertension and Internal Diseases, Pomeranian Medical University in Szczecin

\section{Summary}

Background In this cross-sectional study, we assessed the impact of -344T>C polymorphism of the CYP11B2 gene which encodes aldosterone synthase on 24-hour blood pressure patterns.

Material and methods The study was performed in 137 females with essential hypertension aged 42-60 years. We measured plasma aldosterone level and renin activity (PRA), fasting glucose, lipid profiles and 24-hour urinary sodium and potassium excretion. Based on 24-hour blood pressure monitoring we identified cases with dipping and non-dipping patterns of blood pressure.

Results Mean PRA and aldosterone levels and aldosterone-to-renin ratio (ARR) were within normal range. Non-dipping hypertension was found in $54.3 \%$ of patients. Genotype frequencies of TT, CC and CT were $27 \%, 27 \%$ and $46 \%$, respectively. Carriers of the $\mathrm{C}$ allele had significantly lower nocturnal blood pressure reduction $(\mathrm{P}=0.004)$ and higher nocturnal systolic $(\mathrm{P}=0.02)$ and diastolic blood pressure $(\mathrm{P}=0.044)$, frequency of non-dipping profile $(\mathrm{P}=0.001)$, and 24 -hour urinary potassium excretion $(\mathrm{P}=0.047)$. Urinary sodium excretion was positively correlated with a decrease in nocturnal blood pressure $(R=0.202 ; \mathrm{P}=0.037)$. In a multiple regression analysis, ARR and presence of the $\mathrm{C}$ allele adjusted for confounding variables were inversely associated with the nocturnal blood pressure decline $(\beta=-0.348 ; \mathrm{P}=0.022$ and $\beta=-0.222 ; \mathrm{P}=0.018$, respectively).

Conclusions In conclusion, in middle-aged females with essential hypertension carrying the $\mathrm{C}$ allele we found higher nocturnal blood pressure, lower nocturnal blood pressure reduction, and higher prevalence of non-dipping hypertension than in TT carriers.

key words: hypertension, aldosterone, 24-hour blood pressure, CYP11B2 gene

Arterial Hypertension 2015, vol. 19, no 1, pages: 23-28

DOI: $10.5603 / A H .2015 .0005$

\section{Background}

The prevalence of hypertension in the general population varies from approximately from 30\% to $45 \%$ and is strongly associated with age, gender, race and genetic factors [1]. Among possible mechanisms underlying the development of hypertension, increased activity of the renin-angiotensin-aldoste- rone system (RAAS) seems to play a crucial role [2-9]. It has been suggested that the RAAS activity might be modified by some genetic factors. Earlier studies demonstrated that in women aged $40-70$ years, but not in men; polymorphism of the renin gene was strongly associated with the risk of hypertension [10]. Other studies found the relationship

Address for correspondence: Marta Soltysiak, MD

Klinika Hipertensjologii i Chorób Wewnętrznych, Pomorski Uniwersytet Medyczny

ul. Unii Lubelskiej 1, 71-252 Szczecin, tel: (091) 425-35-50, fax: (091) 425-35-52, e-mail: marta.soltysiak00@gmail.com 
between polymorphism of the aldosterone synthase gene and hypertension [11-13].

Aldosterone synthase (CYP11B2) is a cytochrome P450 enzyme, which catalyses the terminal steps of aldosterone synthesis in the adrenal glands. Common variations of the CYP11B2 gene include the $-344 \mathrm{~T}>\mathrm{C}$ polymorphism (substitution of thymidine to citosine at position -344 in the promoter region) and the C-allele of this gene polymorphism [11-13]. Genetic variations of the CYP11B2 gene which affect its expression in target organs may predispose to the development of essential hypertension [14], low-renin hypertension [11], left ventricular hypertrophy [15], and myocardial infraction [16]. Mitsunobua et al. demonstrated in elderly or male subjects derived from general Japanese population that the CC genotype was associated with lower nocturnal blood pressure and lower prevalence of cardiovascular disease. They suggested a beneficial role of this genotype in maintaining the circadian rhythm of blood pressure [17]. Similarly, Casiglia et al. found in unselected elderly population that systolic blood pressure was significantly lower in subjects with the CC genotype, higher in the TT and intermediate in the CT [18]. On the other hand, other studies failed to demonstrate the differences in blood pressure between TT, CC and CT carriers [19]. Moreover, to our best knowledge, there have been no previous reports assessing the association of CYP11B2 polymorphisms with circadian variations in blood pressure. Therefore, in this study, we investigated possible associations of CYP11B2 genetic variations with RAAS activity and urinary sodium and potassium excretion rates. We were particularly interested in the assessment of potential impact of $-344 \mathrm{~T}>\mathrm{C}$ polymorphism on blood pressure profiles evaluated by 24 -hour monitoring.

\section{Material and methods}

\section{Study population}

The study included 137 women with primary hypertension aged 42-60 years who were hospitalized in the Department of Hypertension and Internal Medicine in Szczecin. We excluded cases with confirmed or suspicious diagnosis of secondary hypertension.

\section{Measurements}

We measured waist circumference, height, and weight and calculated body mass index (BMI). All patients had 24-hour blood pressure monitoring (ABPM) (Spacelabs Healthcare) and we analysed systolic, diastolic, and mean blood pressure during the whole monitoring period, daytime, and night time. Non-dipping blood pressure profile was defined as reduction of $0-10 \%$ in overnight blood pressure. PRA (normal range: $0.51-2.64 \mathrm{ng} / \mathrm{ml} / \mathrm{h}$ ) and plasma aldosterone (normal range: $10-160 \mathrm{pg} /$ $/ \mathrm{ml}$ ) were measured using commercially available assays. From these measurements we calculated the aldosterone-to-renin ratio (ARR). We also evaluated 24-hour urinary potassium (normal range: 25$-125 \mathrm{mmol} / 24 \mathrm{~h}$ ) and sodium (normal range: 40-220 mmol/24 h) excretion, lipid profiles, and fasting glucose.

\section{CYP11B2 genotyping}

Isolation of DNA extracted from whole blood was carried out by using MasterPure ${ }^{\mathrm{TM}}$ Complete DNA Purification kit (Epicentre Technologies; Madison, Wisconsin; USA), which provides the ability to obtain DNA concentration of about $80 \mu \mathrm{g} / \mathrm{ml}$ and purity of $85-90 \%$. The $-344 \mathrm{~T}>\mathrm{C}$ polymorphism of CYP11B2 gene was identified by polymerase chain reaction-restriction fragment length polymorphism, as described elsewhere [20].

\section{Statistical analysis}

Descriptive data are presented as mean \pm SD or numbers and percentage. When comparing normally distributed variables between groups of patients with CC/TC and TT genotype, an independent $t$ test was used for comparing means. For comparison of skewedly distributed variables between the study groups, median values were calculated and Mann-Whitney $U$ test was used. Categorical variables were evaluated by Chi square test. Correlations between nocturnal blood pressure decline and the study variables were evaluated by Spearman's rank correlation. Multiple linear regressions including the presence of the $\mathrm{C}$ allele, ARR, BMI, age, and urine sodium and potassium levels predicted nocturnal blood pressure decline.

\section{Results}

Genotype frequencies of TT, CC and CT were $27 \%, 27 \%$ and $46 \%$, respectively and they were consistent with Hardy-Weinberg equilibrium. Overall, frequencies of CC + CT genotypes were nearly three times higher than the TT genotype (Table I). Majority of subjects were overweight/obese and the mean value of waist circumference was above normal range. As many as $88 \%$ of patients had a positive family history of cardiovascular disease. Additionally, 
Table I. Baseline characteristics of the study participants

\begin{tabular}{|c|c|c|c|}
\hline Continuous variables & Mean & SD & Range \\
\hline Age (years) & 51.87 & 4.92 & $-42-60$ \\
\hline Height $[\mathrm{m}]$ & 1.61 & 18.44 & $-1.61-1.78$ \\
\hline Weight [kg] & 77.23 & 0.06 & $-48.6-148$ \\
\hline Body mass index $\left[\mathrm{kg} / \mathrm{m}^{2}\right]$ & 29.76 & 5.77 & $-18.6-51.52$ \\
\hline Waist circumference [cm] & 96.17 & 13.78 & $-70-133$ \\
\hline 24-hour systolic blood pressure [mmHg] & 121.7 & 16.56 & $-110-160$ \\
\hline 24-hour diastolic blood pressure [mmHg] & 74.77 & 8.56 & $-53-98$ \\
\hline 24-hour mean arterial pressure [mmHg] & 91.82 & 9.68 & $-70-118$ \\
\hline Daytime systolic blood pressure [mmHg] & 125.45 & 13.78 & $-97-162$ \\
\hline Daytime diastolic blood pressure [mmHg] & 77.65 & 8.99 & $-54-100$ \\
\hline Daytime pulse pressure [mmHg] & 47.78 & 8.9 & $-31-82$ \\
\hline Daytime mean arterial pressure [mmHg] & 94.74 & 10 & $-73-118$ \\
\hline Nocturnal systolic blood pressure [mmHg] & 117.1 & 15.24 & $-89-159$ \\
\hline Nocturnal diastolic blood pressure [mmHg] & 69.12 & 9.32 & $-50-98$ \\
\hline Nocturnal pulse pressure [mmHg] & 48.03 & 9.28 & $-31-89$ \\
\hline Nocturnal mean arterial pressure [mmHg] & 86.34 & 10.82 & $-65-121$ \\
\hline Plasma renin activity $[\mathrm{ng} / \mathrm{ml} / \mathrm{h}]$ & 1.88 & 1.75 & $-0.36-12.9$ \\
\hline Aldosterone [ng/dl] & 12.37 & 8.36 & $-2.14-58.6$ \\
\hline Aldosterone-to-renin ratio [ng/dl per ng/ml/h] & 10.61 & 10.72 & $-0.8-99.3$ \\
\hline Glucose [mg/dl] & 96.63 & 15.44 & $-75-189$ \\
\hline Total cholesterol [mg/dl] & 208.23 & 37.29 & $-107-326$ \\
\hline Low density lipoproteins [mg/dl] & 123.81 & 31.63 & $-46-218$ \\
\hline High density lipoproteins [mg/dl] & 55.09 & 17.8 & $-25-82$ \\
\hline Triglycerides [mg/dl] & 141.42 & 71.81 & $-44-467$ \\
\hline Urinary sodium excretion [mmol/24 h] & 140.05 & 63.10 & $-38-359$ \\
\hline Urinary potassium excretion [mmol/24 h] & 43.93 & 17.41 & $-11.1-92.07$ \\
\hline Categorical variables & Number & \multicolumn{2}{|c|}{ Percent } \\
\hline Family history of cardiovascular disease & 120 & \multicolumn{2}{|c|}{87.6} \\
\hline Smokers & 38 & \multicolumn{2}{|c|}{27.7} \\
\hline Diabetes & 22 & \multicolumn{2}{|c|}{16.0} \\
\hline Non-dippers & 75 & \multicolumn{2}{|c|}{54.7} \\
\hline TT genotype & 37 & \multicolumn{2}{|c|}{27.0} \\
\hline TC genotype & 63 & \multicolumn{2}{|c|}{46.0} \\
\hline CC genotype & 37 & \multicolumn{2}{|c|}{27.0} \\
\hline
\end{tabular}

Data are mean $\pm S D$ or numbers (percentage)

$16 \%$ had type 2 diabetes and $28 \%$ were smokers. In 24-hour ABPM more than half of the patients had a non-dipping pattern of blood pressure.

Comparisons in study parameters between CC/ /TC and TT (wild-type genotype) carriers are shown in Table II. Carriers of the $\mathrm{C}$ allele had significantly higher nocturnal blood pressure, lower blood pressure reduction at night time and higher 24-hour urinary potassium excretion. Overall, non-dipping blood pressure profile was much more frequent in patients with CC/TC than in those with TT genotype.

In all women combined, the nocturnal blood pressure decline was not correlated with BMI, waist circumference, aldosterone, PRA and urinary potassium excretion (Table III). There was only a weak positive correlation found between nocturnal blood pressure decline and 24-hour urine sodium 
Table II. Comparison of groups with CYP11B2 polymorphism

\begin{tabular}{|c|c|c|c|}
\hline \multirow[t]{2}{*}{ Variable } & \multicolumn{3}{|c|}{ CYP11B2 polymorphism } \\
\hline & $\mathrm{TC} / \mathrm{CC}(\mathrm{n}=100)$ & $\mathrm{TT}(\mathrm{n}=\mathbf{3 7})$ & $P$ value \\
\hline Age (years) & $51.87 \pm 4.73$ & $51.25 \pm 5.51$ & 0.558 \\
\hline Height $[\mathrm{m}]$ & $1.61 \pm 0.06$ & $1.6 \pm 0.05$ & 0.423 \\
\hline Weight [kg] & $78.15 \pm 16.5$ & $73.51 \pm 11.93$ & 0.281 \\
\hline Body mass index $\left[\mathrm{kg} / \mathrm{m}^{2}\right]$ & $29.98 \pm 5.99$ & $28.43 \pm 4.51$ & 0.372 \\
\hline Waist circumference [cm] & $95.49 \pm 14.22$ & $91.34 \pm 10.38$ & 0.184 \\
\hline 24-hour systolic blood pressure [mmHg] & $122.28 \pm 17.47$ & $119.42 \pm 12.92$ & 0.442 \\
\hline 24-hour diastolic blood pressure [mmHg] & $75.06 \pm 8.46$ & $74.14 \pm 8.24$ & 0.719 \\
\hline 24-hour mean arterial pressure [mmHg] & $92.33 \pm 9.42$ & $90.11 \pm 9.38$ & 0.479 \\
\hline Daytime systolic blood pressure [mmHg] & $126.02 \pm 13.56$ & $123.51 \pm 13.51$ & 0.759 \\
\hline Daytime diastolic blood pressure [mmHg] & $77.58 \pm 8.8$ & $78.11 \pm 9.23$ & 0.683 \\
\hline Daytime pulse pressure [mmHg] & $48.36 \pm 9.1$ & $45.48 \pm 8.07$ & 0.314 \\
\hline Daytime mean arterial pressure $[\mathrm{mmHg}]$ & $94.92 \pm 9.7$ & $94.0 \pm 10.2$ & 0.955 \\
\hline Nocturnal systolic blood pressure [mmHg] & $119.1 \pm 14.94$ & $111.7 \pm 13.41$ & 0.022 \\
\hline Nocturnal diastolic blood pressure [mmHg] & $70.06 \pm 9.32$ & $66.42 \pm 7.95$ & 0.044 \\
\hline Nocturnal pulse pressure [mmHg] & $48.77 \pm 9.51$ & $45.22 \pm 7.87$ & 0.095 \\
\hline Nocturnal mean arterial pressure [mmHg] & $87.50 \pm 10.72$ & $82.57 \pm 9.29$ & 0.034 \\
\hline Nocturnal blood pressure decline [mmHg] & $7.4 \pm 6.61$ & $11.71 \pm 6.49$ & 0.004 \\
\hline Plasma renin activity $[\mathrm{ng} / \mathrm{ml} / \mathrm{h}]$ & $1.83 \pm 1.74$ & $2.09 \pm 1.85$ & 0.755 \\
\hline Urinary sodium excretion [mmol/24 h] & $140.76 \pm 61.99$ & $137.12 \pm 70.02$ & 0.796 \\
\hline Urinary potassium excretion [mmol/24 h] & $45.37 \pm 17.14$ & $40.04 \pm 84.24$ & 0.047 \\
\hline Aldosterone [ng/dl] & $12.84 \pm 8.96$ & $11.63 \pm 7.13$ & 0.580 \\
\hline Aldosterone-to-renin ratio [ng/dl per ng/ml/h] & $11.11 \pm 11.82$ & $9.01 \pm 7.3$ & 0.601 \\
\hline Glucose [mg/dl] & $96.38 \pm 14.4$ & $93.34 \pm 8.89$ & 0.469 \\
\hline Total cholesterol [mg/dl] & $209.47 \pm 37.34$ & $209.6 \pm 36.1$ & 0.661 \\
\hline Low density lipoproteins [mg/dl] & $125.57 \pm 30.86$ & $122.37 \pm 32.14$ & 0.320 \\
\hline High density lipoproteins [mg/dl] & $52.81 \pm 15.15$ & $62.77 \pm 22.83$ & 0.038 \\
\hline Triglycerides [mg/dl] & $142.6 \pm 72.8$ & $131.3 \pm 67.3$ & 0.272 \\
\hline Dippers [n] & $37(37 \%)$ & $25(67.6 \%)$ & 0.001 \\
\hline Non-dippers [n] & $63(63 \%)$ & $12(32.4 \%)$ & 0.001 \\
\hline
\end{tabular}

Data are mean $\pm S D$ or numbers (percentage)

Table III. Correlations of nocturnal blood pressure decline with measured variables

\begin{tabular}{l|c|c}
\hline Variable & R & P value \\
\hline Body mass index $\left[\mathrm{kg} / \mathrm{m}^{2}\right]$ & -0.12 & 0.141 \\
\hline Waist circumference $[\mathrm{cm}]$ & -0.09 & 0.269 \\
\hline Urinary sodium excretion $[\mathrm{mmol} / 24 \mathrm{~h}]$ & 0.20 & 0.037 \\
\hline Urinary potassium excretion $[\mathrm{mmol} / 24 \mathrm{~h}]$ & -0.12 & 0.198 \\
\hline Aldosterone $[\mathrm{ng} / \mathrm{dl}]$ & -0.01 & 0.837 \\
\hline Plasma renin activity $[\mathrm{ng} / \mathrm{ml} / \mathrm{h}]$ & 0.001 & 0.989 \\
\hline Aldosterone-to-renin ratio $[\mathrm{ng} / \mathrm{dl}$ per $\mathrm{ng} / \mathrm{ml} / \mathrm{h}]$ & 0.004 & 0.956 \\
\hline R refers to the Spearman rank correlation coefficient & &
\end{tabular}

$(\mathrm{P}=0.037)$. In a multiple regression analysis, ARR and presence of the $\mathrm{C}$ allele adjusted for confounding variables (age, BMI and urinary sodium and potassium) were inversely associated with the nocturnal blood pressure decline $(\beta=-0.348 ; \mathrm{P}=0.022$ and $\beta=-0.222 ; \mathrm{P}=0.018$, respectively). In carriers of the $\mathrm{C}$ allele, a non-dipping blood pressure profile was positively associated with waist circumference $(\mathrm{OR}=1.066 ; 95 \%$ CI: $1.0-1.13 ; \mathrm{P}=0.034)$.

Further we analysed all women in subgroups with high $(>120 \mathrm{mmol} / 24 \mathrm{~h})$ and low $(\leq 120 \mathrm{mmol} / 24 \mathrm{~h})$ urine sodium (Table IV). We did not find significant 
Table IV. Frequency distribution of blood pressure patterns and CYP11B2 polymorphisms in relation to low and high urinary sodium

\begin{tabular}{|c|c|c|}
\hline & $\begin{array}{l}\text { Urinary sodium } \\
\leq 120 \mathrm{mmol} / 24 \mathrm{~h}\end{array}$ & $\begin{array}{l}\text { Urinary sodium } \\
>120 \mathrm{mmol} / 24 \mathrm{~h}\end{array}$ \\
\hline Dippers & $25(23.5 \%)$ & $27(25.4 \%)$ \\
\hline Non-dippers & $23(21.7 \%)$ & $31(29.2 \%)$ \\
\hline TT genotype & $13(12.3 \%)$ & $15(14.2 \%)$ \\
\hline TC genotype & $22(20.9 \%)$ & $25(23.8 \%)$ \\
\hline CC genotype & $12(11.43 \%)$ & $18(28.5 \%)$ \\
\hline
\end{tabular}

differences in frequencies of dipping and non-dipping patterns of blood pressure $\left(\chi^{2}=0.321 ; \mathrm{P}=0.57\right)$ nor frequencies of CC, CT, and TT genotypes $\left(\chi^{2}=\right.$ $=0.386 ; \mathrm{P}=0.82)$.

\section{Discussion}

In this study, we report for the first time that middle-aged women with essential hypertension who were carriers of the $\mathrm{C}$ allele had significantly higher nocturnal blood pressure, lower nocturnal blood pressure reduction, and higher prevalence of non-dipping hypertension than in TT carriers. Several earlier studies sought associations among genetic variations of the CYP11B2 gene and predisposition to essential hypertension but they yielded inconsistent results. Some authors found that $\mathrm{T}$ allele was frequent in patients with essential hypertension [18, $21,22]$, whereas in other reports the CC genotype and $\mathrm{C}$ allele frequencies were also associated with hypertension [23-25], including results of a large-scale meta-analysis in Chinese [26]. Interestingly, the latter association may be significantly influenced by ethnicity even within the same country [26].

On the other hand, other studies demonstrated that the CC genotype was associated with lower nocturnal [17] and systemic $[13,18]$ blood pressure. Our results strongly suggest that CYP11B2 polymorphisms do not influence markedly the systemic blood pressure, but may have an impact on nocturnal blood pressure and the risk of non-dipping hypertension. These discrepancies in the literature, besides of the impact of ethnicity, may be associated with genetic variations in the CYP11B2 gene across gender [20], age [27, 28], and likely also comorbidities and antihypertensive treatments. In animal model, Chun and Siragy demonstrated that insulin-deficient diabetes increased, whilst lowering blood pressure with sartans and lowering blood glucose with insulin decreased renal cortical and total kidney CYP11B2
mRNA and protein [29]. Consistently with this observation, Bellili et al. found in the general French population that the $-344 \mathrm{~T} / \mathrm{C}$ polymorphism was associated with increased risks for incident type 2 diabetes and metabolic syndrome [13]. Similar suggestions were from study of Ichikava $e t$ al. in which the CT/CC carriers had increased risk of type 2 diabetes by $40 \%$ in comparison to TT carriers [30]. Additionally, recent studies have emphasized that the aldosterone synthase CYP11B2 $(-344 \mathrm{~T}>\mathrm{C})$ gene polymorphism may be a useful predictor of the antihypertensive response to valsartan [25, 29]. Hence, because in our series we found a high prevalence of type 2 diabetes and we routinely use as first-line therapy for hypertension the angiotensin II receptor antagonists including valsartan, we cannot exclude that these factors might have an impact on our results.

It has been suggested that CYP11B2 polymorphism might be associated with salt sensitivity of hypertension [11,31]. It has been estimated that in the general population this genetic variant is recognized in 36\% of patients with salt-sensitive hypertension [32]. In the current study we did not assess salt-sensitivity on different dietary salt regimens but only measured 24-hour urine sodium level, which may reflect, among possible many other causes, individual preferences to high or low sodium intake in the diet [33]. We did not observe significant differences in 24-hour urinary sodium excretion between groups with CT/CC and TT genotypes. We only found a weak inverse correlation between nocturnal blood pressure decline and 24-hour urinary sodium excretion, which was not influenced by allelic variants of the CYP11B2 gene. However, in the multiple regression analysis, nocturnal blood pressure decline was inversely associated with ARR in the presence of the $\mathrm{C}$ allele, regardless of age, BMI, and urine sodium and potassium levels.

In conclusion, in middle-aged females with essential hypertension carrying the $\mathrm{C}$ allele we found higher nocturnal blood pressure, lower nocturnal blood pressure reduction, and higher prevalence of non-dipping hypertension than in TT carriers. These findings suggest genetic predisposition to the development of blunted nocturnal blood pressure dipping and clinical usefulness of $-344 \mathrm{~T}>\mathrm{C}$ polymorphism of CYP11B2 gene in identification of patients at risk for cardiovascular outcomes associated with unfavourable profile of the blood pressure diurnal rhythm.

\section{References}

1. Mancia G., Fagard R., Narkiewicz K. et al. 2013 ESH/ESC Guidelines for the management of arterial hypertension. The Task Force 
for the management of arterial hypertension of the European Society of Hypertension (ESH) and of the European Society of Cardiology (ESC). Eur. Heart. J. 2013; 34: 2159-2219.

2. Narkiewicz K. Układ współczulny a nadciśnienie tętnicze w okresie okołomenopauzalnym. Kardiol. Pol. 2009; 67: 252-253.

3. Schunkert H., Danser A., Hense H., Derkx F., Kurzinger S., Riegger G. Effects of estrogen replacement therapy on the renin-angiotensin system in postmenopausal women. Circulation 1997; 95: 39-45.

4. Fernandez-Vega F., Abellan J., Vegazo O. et al. Angiotensin II type 1 receptor blockade to control BP in postmenopausal women: influence of hormone replacement therapy. Kidney Int. 2002; 62: 36-41.

5. Abhishekh A., Nisarga P., Kisan R. et al. Influence of age and gender on autonomic regulation of heart. J. Clin. Monit. Comput. 2013; 27: 259-264.

6. Vianna L., Hart E., Fairfax S., Charkoudian N., Joyner M., Fadel P. Influence of age and sex on the pressure response following a spontaneous burst of muscle sympathetic nerve activity. Am. J. Physiol. Heart Circ. Physiol. 2012; 11: 2419-2427.

7. Belin de Chantemele E., Mintz J, Rainey W., Stepp D. Impact of leptin-mediated sympathoactivation on cardiovascular function in obese mice. Hypertension 2011; 58: 271-279.

8. Hall J., da Silva A., do Carmo J. Obesity-induced hypertension: role of sympathetic nervous system, leptin and melanocortins. J. Biol. Chem. 2010; 85: 17271-17276.

9. Esler M., Elkelis N., Lambert E., Straznicky N. Neural mechanisms and management of obesityrelated hypertension. Curr. Cardiol. Rep. 2008; 10: 456-463

10. Lima R., Wofford M., Reckelhoff J. Hypertension in postmenopausal women. Curr. Hypertens. Rep. 2012; 14: 254-260.

11. Tamaki S., Iwai N., Tsujita Y., Kinoshita M. Genetic polymorphism of CYP11B2 gene and hypertension in Japanese. Hypertension 1999; 33: 266-270.

12. Rajan S., Ramu P., Shewade D., Adithan C. Promoter region polymorphism of CYP11B2 (344 C>T) gene in healthly volunteers of South Indian Tamilian population. Ind. J. Biotechnol. 2009; 8: 358-362.

13. Bellili N., Foucan L., Fumeron F. et al. Associations of the $-344 \mathrm{~T}>\mathrm{C}$ and the $3097 \mathrm{G}>\mathrm{A}$ polymorphisms of CYP11B2 gene with hypertension, type 2 diabetes, and metabolic syndrome in a French population. Am. J. Hypertens. 2010; 23: 660-667.

14. Tsukada K., Ishimitsu T., Teranishi M. et al. Positive association of CYP11B2 gene polymorphism with genetic predisposition to essential hypertension. J. Hum. Hypertens. 2002; 16: 789-793.

15. Kupari M., Hautanen A., Lankinen L. et al. Associations between human aldosterone synthase (CYP11B2) gene polymorphism and left ventricular size, mass ad function. Circulation 1998; 569-575.

16. Hautanen A., Toivanen P., Manttari M. et al. Joint effects of an aldosterone synthase (CYP11B2) gene polymorphism and classic risk factors on risk of myocardial infarction. Circulation 1999; 100: 2213-2218.

17. Matsubara M., Kikuya M., Ohkubo T. et al. Aldosterone synthase gene (CYP11B2) C-334T polymorphism, ambulatory blood pressure and nocturnal decline in blood pressure in the general Japanese population: the Ohasama Study. J. Hypertens. 2001; 19: 2179-2184.
18. Casiglia E., Tikhonoff V., Mazza A. et al. C-344T polymorphism of the aldosterone synthase gene and blood pressure in the elderly: a population-based study. J. Hypertens. 2005; 23: 1991-1996.

19. Yamagishi K., Tanigawa T., Cui R. et al. Aldosterone synthase gene $\mathrm{T}-344 \mathrm{C}$ polymorphism, sodium and blood pressure in a free-living population: a community-based study. Hypertens. Res. 2007; 30: 497-502.

20. Kumar N., Benjafield A., Lin R., Wang W., Stowasser M., Morris B. Haplotype analysis of aldosterone synthase gene (CYP 11B2) polymorphism shows association with essential hypertension. J. Hypertens. 2003; 7: 1331-1337.

21. Brand E., Chatelain N., Mulatero P. et al. Structural analysis and evaluation of the aldosterone synthase gene in hypertension. Hypertension 1998; 32: 198-204.

22. Sookoian S., Gianotti T.F., Gonzalez C.D., Pirola C.J. Association of the C-344T aldosterone synthase gene variant with essential hypertension: a meta-analysis. J. Hypertens. 2007; 25: 5-13.

23. Tamaki S., Iwai N., Tsujita Y., Kinoshita M. Genetic polymorphism of CYP11B2 gene and hypertension in Japanese. Hypertension 1999; 33: 266-270.

24. Tang W., Wu H., Zhou X. et al. Association of the C-344T polymorphism of CYP11B2 gene with essential hypertension in Hani and Yi minorities of China. Clin. Chimica Acta 2006; 364: 222-225.

25. Ji X., Qi H., Li D.B. et al. Associations between human aldosterone synthase CYP11B2 (-344T/C) gene polymorphism and antihypertensive response to valsartan in Chinese patients with essential hypertension. Int. J. Clin. Exp. Med. 2015; 8: 1173-1177.

26. Cheng X., Xu G. Association between aldosterone synthase CYP11B2 polymorphism and essential hypertension in Chinese: a meta-analysis. Kidney Blood Press. Res. 2009; 32: 128-140.

27. Russo P., Siani A., Venezia A. et al. Interaction between the C(-344) $\mathrm{T}$ polymorphism of CYP11B2 and age in the regulation of blood pressure and plasma aldosterone levels: cross-sectional and longitudinal findings of the Olivetti Prospective Heart Study. J. Hypertens. 2002; 20: 1785-1792.

28. Sarzani R., Salvi F., Dessi-Fulgheri P. et al. Aldosterone synthase alleles and cardiovascular phenotype in young adults. J. Hum. Hypertens. 2003; 17: 859-864.

29. Chun X., Siragy H.M. Local renal aldosterone system and its regulation by salt, diabetes, and angiotensin II type 1 receptor. Hypertension 2005; 46: 584-590.

30. Ichikawa M., Konoshita T., Nakaya T. et al. Genetic variant of the renin-angiotensin system and prevalence of type 2 diabetes mellitus: a modest but significant effect of aldosterone synthase. Acta Diabetol. 2014; 51: 595-599.

31. Rajput C., Makhijani K., Norboo T. et al. CYP11B2 gene polymorphism and hypertension in highlanders accustomed to high salt intake. J. Hypertens. 2005; 23: 79-86.

32. Sanada H., Jones J.E., Jose P.A. Genetics of salt-sensitive hypertension. Curr. Hypertens. Rep. 2011; 13: 55-65.

33. Widecka K., Grodzicki T., Narkiewicz K. et al. Zasady postępowania w nadciśnieniu tętniczym 2011 rok. Wytyczne Polskiego Towarzystwa Nadciśnienia Tętniczego. Nadciśnienie Tętnicze 2011; 15: 55-82. 